\section{Resource Allocation}

\section{through Goal Programming}

\section{KENNETH E. BOTTOMS AND E. T. BARTLETT}

\begin{abstract}
Highlight: One of the major weaknesses of using linear programming in natural resource management is that only a single criterion for determining the optimal strategy is allowed. A goal programming model is presented that allows for multiple, conflicting goals. Results are provided for a management area in northern Colorado. The trade offs between goals are demonstrated by comparison of results from multiple runs in which the order of goal preferences is varied. Goal programming is shown to be a very flexible decision aiding tool which can handle any decision problem formulated by linear programming more efficiently.
\end{abstract}

Public pressure and limited quantities of natural resources necessitate development of more reliable decision making techniques. Modern natural resource managers are rapidly becoming aware of new decision aiding techniques which are capable of reviewing, utilizing, and organizing vast quantities of resource data.

During the past decade, many models utilizing operation research techniques have been developed to aid range and other resource managers. To date, the most common technique used has been linear programming (Nielsen et al., 1966; McConnen et al., 1965; D’Aquino, 1974; Bartlett et al., 1974).

Decision makers realize, however, that linear programming models are single objective or single goal systems; the objective has commonly been profit maximization or cost minimization. Organizations seldom have a single goal; in fact, in public land manage-

Authors are research associate and assistant professor, Department of Range Science, Colorado State University, Fort Collins 80523 .

This research is supported by NSF Grant No. ESR72-03396-A02 to the Regional Systems Program at Colorado State University. Paper presented at the 27 th Annual Meeting, Society for Range Management, Tucson, Arizona, February 3-8, 1974.

The authors wish to acknowledge the assistance of the following people for manuscript review: Dr. C. Wayne Cook, Dr. Donald A. Jameson, and Dr. David R. Betters.

Manuscript received December 11, 1974. ment, the classical economic objective only a low priority. Linear programming has been modified in order to allocate resources when multiple conflicting goals are present (Charnes and Cooper, 1961). The procedure is called goal programming.

The traditional method of solving multiple goal problems has been to define all goals in a common unit (usually dollars). Managers and most economists have been highly critical of this procedure as all goals cannot be translated into strictly economic terms. In goal programming, there is no requirement that the objectives be defined in the same value terms. In fact, multiple goals may be in terms of board feet of timber, number of cattle, or dollars, as well as number of sales and regional incomes.

The only requirement in goal programming is that the manager can attach ordinal priorities or rankings to the goals that reflect the importance of each goal. For example, if the manager has two goals, (1) red meat production and (2) economic efficiency, he must rank one above the other before using goal programming. Once goals have been defined and ranked according to importance, a solution via goal programming can be obtained. The decision maker can then change the goal priorities, and by examining the solutions, he can obtain an estimate of the trade offs between goals. of maximum net revenue often rates
The general logic of goal programming will be discussed, and the application to natural resources explained. A discussion of an application to a forest in northern Colorado has been completed. The results of the goal program have been compared to the results of a linear program.

\section{Goal Programming}

The concept of goal programming evolved as a result of unsolvable linear programming problems and the occurrence of conflicting multiple goals. Many allocation decisions arise in natural resource management because demands on the resource base exceed the supply capability of the ecosystems. In such instances, a linear programming model such as that developed by D'Aquino (1974) will provide the manager with three words, "no feasible solution." Goal programming will provide solutions to infeasible linear programs. In fact, the basic concept of goal programming is "whether goals are attainable or not, an objective may be stated in which optimization gives a result which comes 'as close as possible' to the indicated goals" (Lee, 1972). Goal programming provides the manager with estimates of achievement or nonachievement of his defined and ranked goals.

A simple example is needed to explain goal attainment. Let us assume a manager wanted to carry as close to 500 cow-calf units as possible on his ranch. Goal programming allows either overachievement or underachievement, depending on the particular decision problem. Overachievement would be any point above the 500 level, and underachievement, any point below this level. The objective of goal programming is to minimize the nonachievement of each actual goal level. If nonachievement is minimized to zero, the exact attainment of the goal has been accomplished. Using the example above, the manager might be concerned with minimizing the underachievement, while overachievement might be more than acceptable and therefore not minimized.

For a single-goal problem, the formulation and solution is similar to linear programming with one exception. If complete goal attainment is not possible, goal programming will provide a solution and information to 
the decision maker. In problems with more than one goal, the manager must rank the goals in order of importance. The procedure is to minimize the deviational variables of the highest priority goal, and proceed to the next lower goal. Deviation from this goal is then minimized with the additional constraint that attainment of the first goal cannot be lessened. The other goals are considered in order of priority but lower order goals are only achieved as long as they do not detract from the attainment of higher priority goals. Several solutions can be obtained by changing the priorities in order to indicate how the order of the goals affect planning strategies. ${ }^{1},{ }^{2}$

The goal programming model formulation used was a modification of the one developed by D'Aquino (1974). The difference between the two model formulations, of course, concerns the goals. D'Aquino's model was composed of constraints and a single objective function, in contrast to the goal programming formulation, which contains constraints and multiple objective functions.

Since goal programming requires that each goal be assigned an importance level, the concept results in a multiple objective function wherein the number of objectives is equal to the number of importance levels. Each goal does not, however, result in a separate objective function. If two or more goals can be expressed in the same units of measure, they can be within the same importance level. Dollars of budget and dollars of profit can therefore be represented in the same importance level.

In order to minimize either underor overachievement of a particular goal, a variable called a "deviational variable" is assigned to the goal. This variable represents the magnitude by which the goal level is not achieved. If the value of the deviational variable is small, the goal is more nearly achieved than if the value is relatively large. Thus, the value of the deviational variable is minimized in an attempt to achieve the goal. Optimality occurs

\footnotetext{
${ }^{1}$ Readers desiring an indepth discussion of goal programming should refer to Goal Programming for Decision Analysis by Sang M. Lee.

${ }^{2}$ Additionally $R E A C T I I-A$ Goal Programming Computer Program is available from the RANN Project, Department of Range
} Science, Colorado State University.

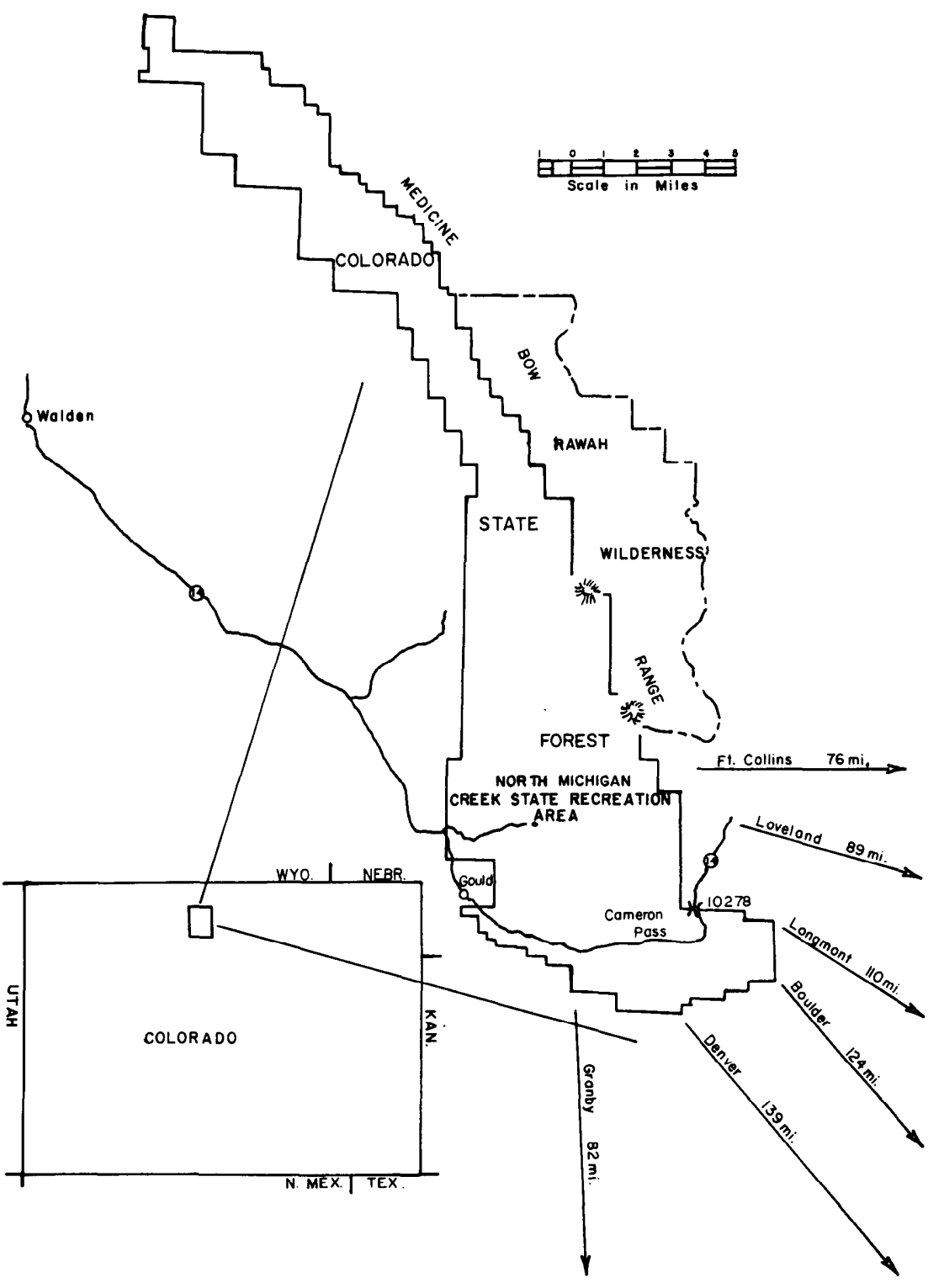

Fig. 1. The geographic location of the Colorado State Forest.

when the deviational variables of the different goals have been minimized to the smallest possible value in order of importance.

\section{Study Area}

Goal programming was applied to a resource decision problem on the mountainous Colorado State Forest, located in northern Colorado (Fig. 1). The area is approximately 9,050 acres of the southern portion of the State Forest, which ranges in elevation from 8,500 feet to over 11,000 feet. The area has been, and may increasingly become, a conflict area due to its location and its basic resource composition.

Winter may begin the last of August and continue through May. Therefore, resource use is concentrated in the 3-month period from June to August.
Average precipitation ranges between 18 and 21 inches annually, with most precipitation falling as snow.

Soils in this area vary greatly but are composed mostly of granitic residues on shale or slate. Soil depth varies from 15 to 25 inches. Most of the forest soils are very susceptible to slippage and tend to be somewhat acidic. Soils in this area are very susceptible to erosion; when used intensively, great care should be taken to prevent the potential erosion.

Vegetation of the study site is extremely diverse and can be broken into several distinct types: willow carrs and marshy meadows, grassland meadows, sagebrush meadows, spruce-fir forests, lodgepole pine forests, and sagebrush-lodgepole ecotones. Acreage for each type is shown in Table 1. 
Table 1. Acreage by major vegetative types.

\begin{tabular}{lc}
\hline \multicolumn{1}{c}{ Vegetative type } & $\begin{array}{c}\text { Area } \\
\text { (acres) }\end{array}$ \\
\hline Grassland meadows & 1950 \\
Sagebrush meadows & 2000 \\
Spruce-fir & 1450 \\
Lodgepole pine & 2600 \\
Willow bottomland & 570 \\
Sagebrush-lodgepole ecotone & 480 \\
Total acres & 9050 \\
\hline
\end{tabular}

Lakes cover an additional 82 acres with approximately 10.4 miles of streams. The major streams are the North Fork of the North Michigan River, its tributaries, and Grass Creek. The annual discharge from the approximately 18-square-mile area of this watershed is nearly 12,500 acre feet. Sedimentation also occurs and an average production of 7.5 tons/acre/ year is considered a reasonable limit.

Recreational resources are many. The 66-acre North Michigan Reservoir along with several miles of trout stream provides a varied trout fishery, including cutthroat, rainbow, and brook trout. Camping also accounts for a significant portion of the recreational use, in addition to hiking and backpacking.

The timber resource at present is capable of yielding approximately 1,275 cubic feet of lodgepole pine and 200 cubic feet of spruce-fir per acre in each of the respective ecosystems.

Results of pellet group counts give estimates of deer and elk populations that range between .12 and .15 days use per acre, which is typically related to total deer and elk population levels. Considering only areas on the site that are believed to be valuable to deer and elk, it was thought that approximately 50-60 deer and 50-60 elk frequent the area during the available season of 150 days.

\section{Model Formulation}

Several products have been identified on the study area: cow-calf months of grazing, steer months of grazing, recreation user days of camping, board feet of lodgepole pine and spruce-fir timber, and deer and elk months of grazing. Each of the products is derived from one or more of the seven available resources of the study area: domestic forage, phosphorus, protein, wildlife forage, fish, lodgepole pine, and spruce-fir. Table 2 outlines the quantities of the resources needed to produce one unit of each product. These values are based on the best available research results for areas similar to the study area.

Within each of the six vegetation types, several management alternatives have been defined, each of which would be expected to change the levels of production and some of the resources. Estimates of the expected effect of the management alternatives of the yields of the various resources for each of the vegetation types, together with projected unit costs, are summarized in Tables 3 through 8 . These estimates were based either on existing data in the area or research conducted on similar areas (Morrison, 1949; Stoddart and Smith, 1955; Vallentine, 1971; and Cook, 1968). The rates for the recreation user days were calculated on an opportunity cost basis in which the acreage was assumed used for recreational purposes and therefore removed from other resource production.

Non-product-oriented goals in Table 9 were identified for management. Goals as used here became linear equations, each of which must be composed of homogeneous units al-

Table 2. Quantities of resources needed to produce one unit of each product.

\begin{tabular}{|c|c|c|c|c|c|c|c|}
\hline \multirow[b]{2}{*}{ Resources } & \multicolumn{7}{|c|}{ Products } \\
\hline & $\begin{array}{l}\text { Cow-calf } \\
\text { months of } \\
\text { grazing }\end{array}$ & $\begin{array}{c}\text { Steer } \\
\text { months } \\
\text { of grazing }\end{array}$ & $\begin{array}{l}\text { Recreation } \\
\text { user days } \\
\text { of camping }\end{array}$ & $\begin{array}{c}\text { MBF } \\
\text { lodgepole } \\
\text { pine }\end{array}$ & $\begin{array}{c}\text { MBF } \\
\text { spruce-fir }\end{array}$ & $\begin{array}{c}\text { Deer } \\
\text { months } \\
\text { of grazing }\end{array}$ & $\begin{array}{c}\text { Elk } \\
\text { months } \\
\text { of grazing }\end{array}$ \\
\hline Domestic forage $(\mathrm{lb}) *$ & 1209 & 776 & 0.042 & & & 753. & 3080. \\
\hline Phosphorus (lb) ${ }^{* *}$ & 2.51 & 1.55 & & & & & \\
\hline Protein $(\mathrm{lb}) * *$ & 141.4 & 77.6 & & & & & \\
\hline Wildlife forage (lb)* & & & 0.057 & & & 5270 & 5133 \\
\hline Fish (lb) & & & 1.5 & & & & \\
\hline Lodgepole pine (bd ft) & & & & 1000. & & & \\
\hline Spruce-fir (bd ft) & & & & & 1000. & & \\
\hline Revenue $(\$)$ & 5.40 & 4.50 & & 174. & 408. & & \\
\hline
\end{tabular}

\footnotetext{
*Domestic and wildlife forage are considered only to be the amount that is usable under proper stocking rates.

**Phosphorus and protein amounts also included as part of domestic forage.
}

Table 3. Yields of resources on willow bottomland (570 acres) under various management alternatives.

\begin{tabular}{|c|c|c|c|c|c|c|c|c|c|}
\hline \multirow[b]{2}{*}{ Resources } & \multicolumn{8}{|c|}{ Alternative } & \multirow[b]{2}{*}{ Units } \\
\hline & $\begin{array}{c}\text { No } \\
\text { action }\end{array}$ & $\begin{array}{l}\text { Drainage } \\
\text { of wet } \\
\text { lands }\end{array}$ & $\begin{array}{l}\text { Aerial } \\
\text { spraying } \\
\text { of willow } \\
\text { land }\end{array}$ & $\begin{array}{c}\text { Aerial } \\
\text { spraying } \\
\text { with grass } \\
\text { seeding } \\
\end{array}$ & $\begin{array}{c}\text { Mechanical } \\
\text { removal } \\
\end{array}$ & $\begin{array}{c}\text { Mechanical } \\
\text { removal } \\
\text { with grass } \\
\text { seeding } \\
\end{array}$ & $\begin{array}{l}\text { Fcrtili- } \\
\text { zation }\end{array}$ & $\begin{array}{l}\text { Campground } \\
\text { development }\end{array}$ & \\
\hline Size of action & 1.0 & 1.0 & 1.0 & 1.0 & 1.0 & 1.0 & 1.0 & 3.0 & Acres \\
\hline Sediment & 2.5 & 6.5 & 5.0 & 4.35 & 9.5 & 8.5 & 2.0 & 27.0 & Tons/acre/year \\
\hline Domestic forage & 1270.0 & 1459.0 & 1647.0 & 1730.0 & 1786.0 & 2249.0 & 2006.0 & & Pounds/acre \\
\hline Phosphorus & 2.54 & 2.92 & 3.30 & 3.46 & 3.57 & 4.50 & 4.01 & & Pounds/acre \\
\hline Protein & 94.0 & 108.0 & 122.0 & 128.0 & 132.0 & 161.0 & 148.0 & & Pounds/acre \\
\hline Wild life forage & 1500.0 & 975.0 & 150.0 & 75.0 & 750.0 & 375.0 & 1875.0 & 2250.0 & Pounds/acre \\
\hline Fish & & & & & & & & 2000.0 & $\begin{array}{l}\text { Pounds stocked/ } \\
\text { year }\end{array}$ \\
\hline Recreation & & & & & & & & 1750.0 & User days \\
\hline Variable cost & 0.00 & 125.00 & 3.50 & 8.50 & 25.00 & 25.50 & 6.00 & 2700.0 & $\begin{array}{l}\text { Dollars/unit } \\
\text { action }\end{array}$ \\
\hline
\end{tabular}


Table 4. Yields of resources on sagebrush vegetation type (2,000 acres) under various management alternatives.

\begin{tabular}{|c|c|c|c|c|c|c|c|c|c|}
\hline \multirow[b]{2}{*}{ Resources } & \multicolumn{8}{|c|}{ Alternative } & \multirow[b]{2}{*}{ Units } \\
\hline & $\begin{array}{c}\text { No } \\
\text { action }\end{array}$ & $\begin{array}{l}\text { Mechanical } \\
\text { removal }\end{array}$ & $\begin{array}{c}\text { Mcchanical } \\
\text { removal } \\
\text { with grass } \\
\text { seeding }\end{array}$ & $\begin{array}{l}\text { Mechanical } \\
\text { removal } \\
\text { grass seeding } \\
\text { fertilization }\end{array}$ & $\begin{array}{c}\text { Aerial } \\
\text { spraying }\end{array}$ & $\begin{array}{c}\text { Aerial } \\
\text { spraying } \\
\text { with grass } \\
\text { seeding }\end{array}$ & $\begin{array}{l}\text { Spraying } \\
\text { grass seeding, } \\
\text { fertilization }\end{array}$ & $\begin{array}{c}\text { Grass } \\
\text { interseeding }\end{array}$ & \\
\hline Size of action & 1.0 & 1.0 & 1.0 & 1.0 & 1.0 & 1.0 & 1.0 & 1.0 & Acres \\
\hline Sediment & 9.75 & 10.0 & 9.25 & 7.00 & 5.75 & 5.5 & 5.0 & 6.5 & Tons/acre/year \\
\hline Domestic forage & 825.0 & 1918.0 & 2475.0 & 2681.0 & 1031.0 & 1116.0 & 1256.0 & 947.0 & Pounds/acre \\
\hline Phosphorus & .99 & 2.30 & 2.97 & 3.22 & 1.24 & 1.34 & 1.51 & $1.14 \mathrm{~F}$ & Pounds/acre \\
\hline Protein & 33.8 & 78.7 & 161.0 & 110.0 & 42.3 & 45.7 & 51.5 & $38.8 \quad \mathrm{~F}$ & Pounds/acre \\
\hline Wildlife forage & 2500.0 & 1000.0 & 875.0 & 750.0 & 1500.0 & 1375.0 & 1125.0 & $2375.0 \quad \mathrm{~F}$ & Pounds/acre \\
\hline Variable cost & 0.00 & 15.00 & 17.50 & 32.50 & 3.00 & 18.00 & 20.50 & $7.50 \mathrm{I}$ & $\begin{array}{l}\text { Dollars/unit } \\
\text { action }\end{array}$ \\
\hline
\end{tabular}

though the units may differ between goals. The goal level is the amount of each goal unit desired, such as number of cow months, board feet of timber, acre feet of water, etc.

The initial results indicate that goal programming will mimic the linear programming solution if the objective function of the linear program is the lowest priority goal or if only one objective is considered in the goal program. Conventional linear programming requires all constraints be met before profit is maximized. The same requirement must be made of goal programming before it can mimic linear programming. Setting all goals at a higher priority than the linear programming objective or only using one objective accomplishes the same end. The goals, goal levels, and priorities are shown in Table 9. In the linear program, profit maximization was the objective function and the remaining eight goals were entered as minimum constraint requirements.

The results from the linear and goal programs were identical with all goals being met or exceeded. The number of steers and amount of lodgepole pine and spruce-fir timber were exceeded

Table 5. Yields of resources on sagebrush-lodgepole ecotone (480 acres) under various management alternatives.

\begin{tabular}{|c|c|c|c|c|}
\hline \multirow[b]{2}{*}{ Resources } & \multicolumn{3}{|c|}{ Alternatives } & \multirow[b]{2}{*}{ Units } \\
\hline & No action & $\begin{array}{l}\text { Campground } \\
\text { development }\end{array}$ & $\begin{array}{c}\text { Wildlife } \\
\text { habitat } \\
\text { development }\end{array}$ & \\
\hline Size of action & 1.0 & 3.0 & 1.0 & Acres \\
\hline Sediment & 5.65 & 25.35 & 9.82 & Ton/acre/year \\
\hline Domestic forage & 525.0 & & & Pounds/acre \\
\hline Phosphorus & .79 & & & Pounds/acre \\
\hline Protein & 28.4 & & & Pounds/acre \\
\hline Wild life forage & 1418.0 & 2979.0 & 2128.0 & Pounds/acre \\
\hline Fish & & 3200.0 & & Pounds stocked/year \\
\hline Recreation & & 2700.0 & & User days \\
\hline Variable cost & 0.00 & 2500.00 & 350.00 & Dollars/unit action \\
\hline
\end{tabular}

because of the contribution to the objective function of the linear program or the profit goal in the goal program. The ecosystems produced an ample amount of wildlife forage; consequently, animal numbers exceeded the minimum. With two exceptions the ecosystems were managed under the "no action" alternative. One campground was constructed in the sagebrush-lodgepole ecotone and four patchcuts for wildlife were indicated in the spruce-fir community.

The goal program was reexamined after raising the budget level to
$\$ 90,500$ and then to $\$ 135,750$ (Table 9). Profit increased as a result of an increase in spruce-fir production and a slight increase in steers without an increase in cows. The only change in the management alternatives was an increase in the number of patchcuts in the spruce-fir ecosystem.

Some goals of the model were increased, as indicated in Table 10. A linear program will not aid the decision maker in this case, because the ecosystem is not capable of producing all of the goals simultaneously at the given budget levels.

Table 6. Yiclds of resources on lodgepole type (2,600 acres) under various management alter natives.

\begin{tabular}{|c|c|c|c|c|c|c|}
\hline \multirow[b]{2}{*}{ Resources } & \multicolumn{5}{|c|}{ Alternatives } & \multirow[b]{2}{*}{ Units } \\
\hline & No action & $\begin{array}{l}\text { Clearcut } \\
\text { harvest }\end{array}$ & $\begin{array}{c}\text { Clearcut } \\
\text { replant } \\
\text { nursery stock }\end{array}$ & $\begin{array}{l}\text { Patch } \\
\text { cutting }\end{array}$ & $\begin{array}{l}\text { Campground } \\
\text { development }\end{array}$ & \\
\hline Size of action & 1.0 & 1.0 & 1.0 & 40.0 & 3.0 & Acres \\
\hline Sediment & 6.5 & 9.05 & 7.65 & 350.0 & 27.75 & Tons/acre/year \\
\hline Domestic forage & 225.0 & 786.0 & & 28064.0 & & Pounds/acre \\
\hline Phosphorus & .38 & 1.34 & & 47.6 & & Pounds/acre \\
\hline Protein & 15.0 & 52.6 & & 1880.0 & & Pounds/acre \\
\hline Wild life forage & 337.0 & 565.0 & 168.0 & 26941.0 & 606.0 & Pounds/acre \\
\hline Fish & & & & & 1500.0 & Pounds stocked/year \\
\hline Recreation & & & & & 2000.0 & User days \\
\hline Lodgepole pine & 562.5 & 11250.0 & 14062.0 & 18000.0 & & Board feet \\
\hline Variable cost & 0.00 & 400.00 & 489.00 & 11000.00 & 2700.00 & Dollars/unit action \\
\hline
\end{tabular}


Table 7. Yields of resources on spruce-fir type (1,450 acres) under various management alternatives.

\begin{tabular}{|c|c|c|c|c|c|c|c|}
\hline \multirow[b]{2}{*}{ Resources } & \multicolumn{6}{|c|}{ Alternatives } & \multirow[b]{2}{*}{ Units } \\
\hline & No action & Clearcut & $\begin{array}{c}\text { Clearcut } \\
\text { replant } \\
\text { nursery stock }\end{array}$ & $\begin{array}{l}\text { Selective } \\
\text { cut }\end{array}$ & $\begin{array}{l}\text { Patchcut } \\
\text { for wildlife }\end{array}$ & $\begin{array}{c}\text { Campsite } \\
\text { development }\end{array}$ & \\
\hline Size of action & 1.0 & 1.0 & 1.0 & 1.0 & 40.0 & 3.0 & Acres \\
\hline Sediment & 7.0 & 9.25 & 9.7 & 9.75 & 350.00 & 28.5 & Tons/acre/year \\
\hline Domestic forage & 40.0 & 1.0 & & 348.0 & 14744.0 & & Pounds/acre \\
\hline Phosphorus & 0.39 & 0.78 & & 0.59 & 25.2 & & Pounds/acre \\
\hline Protein & 15.4 & 30.9 & & 23.2 & 988.0 & & Pounds/acre \\
\hline Wildlife forage & 125.0 & 200.0 & 100.0 & 250.0 & 12480.0 & 112.5 & Pounds/acre \\
\hline Fish & & & & & & 1200.0 & Pounds stocked/year \\
\hline Recreation & & & & & & 500.0 & User days \\
\hline Spruce-fir & 350.0 & 7000.0 & 7700.0 & 2100.0 & 280000.0 & & Board feet \\
\hline Variable cost & 0.00 & 452.00 & 510.00 & 376.00 & 10000.00 & 2700.00 & Dollars/unit action \\
\hline
\end{tabular}

Table 8. Yields of resources on grassland type (1,950 acres) under various management alternatives.

\begin{tabular}{lcccccl}
\hline \hline & \multicolumn{7}{c}{ Alternatives } & & \\
\cline { 2 - 5 } Resources & No action & Interseeding & $\begin{array}{c}\text { Disking and } \\
\text { interseding }\end{array}$ & $\begin{array}{c}\text { Disk, interseed } \\
\text { and fertilizer }\end{array}$ & \multicolumn{1}{c}{ Disk } & Units \\
\hline Size of action & 1.0 & 1.0 & 1.0 & 1.0 & 1.0 & Acres \\
Sediment & 1.5 & 3.5 & 8.25 & 8.0 & 8.5 & Tons/acre/year \\
Domestic forage & 2450.0 & 2817.0 & 3062.0 & 3552.0 & 2940.0 & Pounds/acre \\
Phosphorus & 3.92 & 4.51 & 4.90 & 5.63 & 4.7 & Pounds/acre \\
Protein & 66.2 & 76.1 & 82.7 & 95.9 & 79.4 & Pounds/acre \\
Wildlife forage & 625.0 & 469.0 & 250.0 & 125.00 & 312.0 & Pound s/acre \\
Variable cost & 0.00 & 6.50 & 7.95 & 12.45 & 7.00 & Dollars/unit action \\
\hline
\end{tabular}

Table 9. Results of linear and goal programs with varying budget levels.

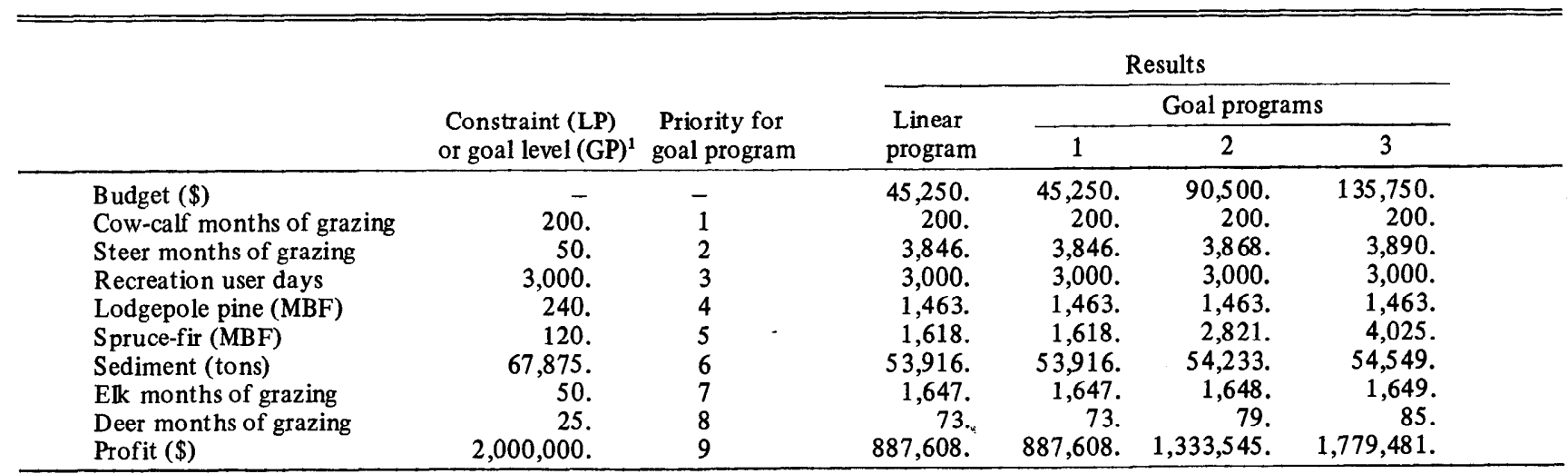

${ }^{1} \mathrm{LP}=$ linear programming; GP = goal programming.

Table 10. Results of goal program as goal priorities change.

\begin{tabular}{|c|c|c|c|c|c|c|c|c|c|}
\hline \multirow[b]{2}{*}{ Goal } & \multirow[b]{2}{*}{ Goal level } & \multicolumn{2}{|c|}{ Run 1} & \multicolumn{2}{|c|}{ Run 2} & \multicolumn{2}{|c|}{ Run 3} & \multicolumn{2}{|c|}{ Run 4} \\
\hline & & $\begin{array}{l}\text { Goal } \\
\text { priority } \\
\text { ranking }\end{array}$ & $\begin{array}{c}\text { Level } \\
\text { achieved }\end{array}$ & $\begin{array}{c}\text { Goal } \\
\text { priority } \\
\text { ranking }\end{array}$ & $\begin{array}{c}\text { Level } \\
\text { achieved }\end{array}$ & $\begin{array}{c}\text { Goal } \\
\text { priority } \\
\text { ranking }\end{array}$ & $\begin{array}{c}\text { Level } \\
\text { achieved }\end{array}$ & $\begin{array}{c}\text { Goal } \\
\text { priority } \\
\text { ranking }\end{array}$ & $\begin{array}{c}\text { Level } \\
\text { achieved }\end{array}$ \\
\hline Profit (\$) & $2,000,000$ & 1 & 926,337 & 4 & 434,500 & 4 & 434,500 & 4 & $2,000,000$ \\
\hline Cow-calf months of grazing & 200 & 2 & & 2 & 200. & 2 & 200. & 2 & 200. \\
\hline Steer months of grazing & 50. & 3 & 4,214 . & 3 & 3,808 . & 1 & 3,808 & 3 & 5,229 . \\
\hline Recreation user days & 45,000 . & 4 & 0. & 1 & 38,613 . & 3 & 38,613 . & 1 & 45,000 . \\
\hline Lodgepole pine (MBF) & 240. & 5 & 1,463 . & 5 & 1,463 . & 5 & 1,463 & 5 & $1,153$. \\
\hline Spruce-fir (MBF) & 120. & 6 & 1,711 . & 6 & 508. & 6 & 508. & 6 & 7,759 \\
\hline Sediment (tons) & 67,875 & 7 & 53,929 . & 7 & 53,764 . & 7 & 53,764 & 7 & 64,139 . \\
\hline Elk months of grazing & 500. & 8 & 1,107 . & 8 & 1,096 . & 8 & 1,096 & 8 & 1,418 \\
\hline Deer months of grazing & 600. & 9 & 600. & 9 & 600. & 9 & 600. & 9 & 600 \\
\hline Budget (\$) & 45,250 . & - & - & - & - & - & - & 10 & $1,391,089$ \\
\hline
\end{tabular}


Conflict for scarce resources forces the manager to sacrifice some of his goals in order to meet others. Multiple runs using linear programming would not show any trade offs between goals and would be many times more expensive. In such a situation, information concerning the trade off between goals would greatly aid the resource manager. To provide such information, the goal programming model was solved using several different orders of goal priorities. Such varying of the order of goals will be defined as parametric goal programming.

Table 10 outlines the results of the three parametric goal programming runs, each of which has a different top priority goal. Table 10 also shows how the results differ if the budget is entered as a goal instead of a fixed constraint.

Run one was based on profit maximization as the top priority goal. Steers were favored over cow-calf units, spruce-fir over lodgepole pine with no user days produced. The only alternative other than "no action" alternatives was 4.5 forty-acre patchcuts in spruce-fir. The profit generated was $\$ 926,337$. All goals, whether completely achieved or not, were met to the fullest possible extent given the priority ranking.

The second test had user day production as the highest priority goal with priority of profit dropping to fourth. User day production increased to 38,613 , which is the maximum given a fixed budget of $\$ 45,250$. Eighteen campgrounds were indicated on the sagebrush-lodgepole ecotone. The cow-calf goal was met in this run because profit was no longer overriding this alternative. Steer production dropped because of recreation and the presence of cow-calves. Spruce-fir production dropped because the budget was consumed in recreation development instead of timber harvesting; thus no patchcuts were indicated.
Elk numbers decreased slightly because of the overall decrease in wildlife forage being produced on the area. The profit was approximately one-half that of the first run.

The third test had steer production as the highest goal, followed by cowcalf, recreation, and profit. The results are the same as when recreation was the highest goal because the low goal level is met on all runs. This indicates to the manager that steer production is not a critical goal except as it relates to profit.

In the last test, the budget constraint was changed from a constraint to the last priority goal (tenth). In this case, all levels of the other goals were met but at a cost of $\$ 1,391,089$. This is over 30 times the budget level of $\$ 45,250$. The management alternatives indicated in the solution are shown in Table 11.

\section{Conclusions}

The public ideally views the soundness of a decision-making process by the degree that goals are achieved by a decision. Goal programming measures the degree of goal attainment and has the ability to solve problems involving multiple conflicting goals according to an ordinal priority structure.

Goal programming enables the manager to program multi-objective problems. Goal programming is particularly applicable as a planning aid to agencies such as the Forest Service and the Bureau of Land Management, where multiple resource management is essential.

The goal-programming procedure is one more tool available to natural resource decision makers. We, as resource managers, must strive to improve our decision-making processes. Any tool which can, in any way, aid the decision maker in arriving at good solutions to complex problems should be reviewed, evaluated, and used when feasible.
Model formulations have shown great promise as effective decisionaiding tools for natural resource allocation (D'Aquino, 1974; Bartlett et al., 1974). The idea of using the level of goal attainment as objective functions rather than the conventional profit or cost seems to more closely approximate the actual thinking process of the manager. Quantification of this nature sets the foundation for an iterative updating system so necessary if operation research tools are to be used in practical applications to natural resource allocation processes.

\section{Literature Cited}

Bartlett, E. T., G. R. Evans, and R. E. Bement. 1974. A serial optimization model for ranch management. J. Range Manage. 27:233-239.

Charnes, A., and W. W. Cooper. 1961. Management models and industrial applications of linear programming: I and II. John Wiley and Sons, Inc., N.Y.

Cook, C. Wayne, and L. E. Harris. 1968. Nutritive value of seasonal ranges. Utah State Univ. Agr. Exp. Sta. Bull. No. 472, Logan. $55 \mathrm{p}$.

D'Aquino, Sandy A. 1974. Optimum allocation of resources: A programming approach. J. Range Manage. 27:228-233.

Lee, Sang M. 1972. Goal programming for decision analysis. Auerbach Publishers Inc., Philadelphia, Pa. 387 p.

McConnen, R. J, D. K. Navon, and E. L. Amidon. 1965. Efficient development and use of forest lands: An outline of a prototype computer-oriented system for operation planning, p 18-32. In Mathematical models in forest management. Forestry Commission, Forest Record No. 59.

Morrison, Frank B. 1949. Feeds and feeding. The Morrison Publishing Company, Ithaca, N.Y. 1207 p.

Nielsen, Darwin B., William G. Brown, Dillard H. Gates, and Thomas R. Bunch. 1966. Economics of federal range use and improvement for livestock production. Oregon Agr. Exp. Sta. Tech. Bull. No. 92.40 p.

Stoddart, Laurence A., and Arthur D. Smith. 1955. Range management. MoGraw-Hill Book Co., Inc., N.Y. 433 p.

Vallentine, John F. 1971. Range developments and improvements. Brigham Young Univ. Press, Provo, Utah. 516 p.

Table 11. Management alternatives selected under the goal program with budget as a last priority rather than a constraint goal.

\begin{tabular}{lc} 
Alternative & Amount \\
\hline Fertilization of willow bottomland (acres) & 570. \\
Campgrounds in sagebrush-lodgepole ecotone ( 3 acres) & 0. \\
Wildlife habitat development in sagebrush-lodgepole ecotone (3 acres) & 480. \\
Patchcut for wildlife in lodgepole pine (40 acres) & 64. \\
Campgrounds in lodgepole pine (3 acres) & 12.3 \\
Selective cut in spruce-fir (acres) & 313. \\
Patchcut for wild life in spruce-fir (40 acres) & 25. \\
Campgrounds in spruce-fir (3 acres) & 41. \\
\hline
\end{tabular}

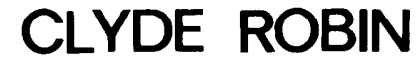

NATIVE SEEDS

Castro Valley, California 94546 